\title{
The Changing Lattice of Languages, Borders, and Identities in Silesia ${ }^{1}$
}

\author{
Tomasz Kamusella
}

\section{Introduction: Territory, Borders...}

Since Enea Silvo de'Piccolomini (later, Pope Pius II) mentioned in his 1458 treatise, De Europa (On Europe), the Oder (Odra) River as the dividing line between those Silesian territories inhabited by Germanicand by Slavic-speakers, (Lubos 1995: 68) language difference has become part and parcel of the region's history. However, until the rise of ethnolinguistic nationalism across Central Europe in the wake of the Napoleonic Wars, it had been a minor element of a person's identity; the main socio-political cleavage was that between members of the estates (that is, nobility, clergy and, to a lesser degree, richer burghers) and serfs. The legally imposed social and spatial immobility of the serfs also kept the language boundary stable from the late Middle Ages into the Early Modern period. On the other hand, when the need arose, the divide was easily straddled by specialists mediating among members of an immobile peasantry and (though to a lesser extent) of burgher communities. These specialists included clergy and nobility (usually landowners) who were literate in Latin and German (or rather a German, meaning a chancery variety of what today we, anachronistically, tend to dub the unambiguously unitary German language). Within this group one can also include (law court) scribes, inn-owners, itinerant craftsmen, and merchants. In the $18^{\text {th }}$ century, French (or the Romance dialect of Paris) joined Latin and German, having become a specific sociolect of the European nobility and bourgeoisie, and it retained this role until immediately after World War II.

This identification of Silesia west of the Oder as Germanicspeaking and east of the river as Slavophone had its beginning in the

\footnotetext{
${ }^{1}$ I wish to thank Cormac Ó Cuilleanáin for his remarks on the phenomenon of dialect continuum and for turning my attention to G Celati's story(1989), a fragment of which originally adorned the article as its motto. As usual, I am also grateful to Michael O Gorman and Catherine Gibson for their careful and precise corrections and suggestions.

On the basis of an earlier draft of the text, on 19 December 2009, I delivered a lecture at the start-up conference, Reshaping Japan's Border Studies, within the framework of the Global Center of Excellence Program, Slavic Research Center, University of Hokkaido, Sapporo, Japan.
} 
eastward flow of (overwhelmingly) Germanic-speaking settlers from the relatively overpopulated Holy Roman Empire. In the case of Silesia this process commenced in the $12^{\text {th }}$ century. Subsequently, in the wake of the post-1138 fragmentation of the Duchy of Poland (which was not reversed until the early $14^{\text {th }}$ century), it was fortified by the inclusion of the largely independent Silesian principalities among the lands of the Czech Crown, territories which constituted part of the empire. (Krallert et al 1958: 3) Hence, in a piecemeal manner, Silesia found itself incorporated within the frontiers of the Holy Roman Empire during the first half of the $14^{\text {th }}$ century, and the Polish king renounced his right to the region in 1348. Since then, Silesia found itself outside the history of Polish statehood until 1922.

In 1526, Silesia, as one of the lands of the Czech Crown, together with the crown's other lands (most significantly, Bohemia and Moravia), became part of the complex of the hereditary lands of the Habsburgs which encompassed the south of the empire and the Kingdom of Hungary (or this polity's section not controlled by the Ottomans). This situation lasted until the sudden ascendancy of Prussia in the first half of the $18^{\text {th }}$ century. In 1740-42, Berlin seized seven-eighths of Silesia from Vienna. The territory which remained with the Habsburgs mainly consisted of the southern sliver of Upper Silesia. ${ }^{2}$ With time it became known as Austrian Silesia, and because it actually comprised two territories separated by a Moravian wedge, one tended to refer to West (Austrian) Silesia with its center in the crownland's capital of Troppau (Opava) and to East (Austrian) Silesia with its center in Teschen. ${ }^{3}$ Likewise, the Hohenzollerns' territorial gain was dubbed Prussian Silesia. When administrative reforms were introduced in Prussia in 1815-20, the Regency (Regierungsbezirk) of Oppeln (Opole) ${ }^{4}$ came to coincide with Upper Silesia, while Lower Silesia was divided between the regencies of Breslau (Wrocław) and Liegnitz (Legnica). (Stüttgen et al 1976: 266)

On the ecclesiastical plane, almost all of Silesia was contained within the Diocese of Breslau, with the exception of the southernmost

\footnotetext{
${ }^{2}$ The division of Silesia into Lower Silesia (or the western two-thirds of the region) and Upper Silesia (or the region's eastern one-third) came about in the second half of the $15^{\text {th }}$ century, when the Hungarian King, Matthias Corvinus, ruled over the Czech lands of Silesia and Moravia. At that time, Silesia was also institutionalized as an administrative region. Obviously, it had coalesced into a region per se earlier, in the late $10^{\text {th }}$ century, when would-be Poland had seized the land from Bohemia. (Cf Kries 1842: 1; Orzechowski 1971: 2)

${ }^{3}$ In 1920 the eastern half of Austrian Silesia was divided between Czechoslovakia and Poland, and its main city was similarly divided. Today, Poland's part of Teschen is Cieszyn, and the Czech Republic's part is Český Těšín.

${ }^{4}$ I employ forms of place-names that were current in a given time period; on the first mention of a locality, I provide today's official form of its name in parentheses.
} 
section of Prussian Upper Silesia which was part of the Moravian Archdiocese of Olmütz (Olomouc). Across the border in the Habsburg lands, East Silesia, alongside the western half of West Silesia, belonged to the Breslau Diocese, whereas the rest of West Silesia belonged to the Archdiocese of Olmütz. Until 1811, the easternmost section of Prussia's Upper Silesia, extending between Beuthen (Bytom) and Ple $\beta$ (Pszczyna), belonged to the Polish Diocese of Cracow before it passed to the jurisdiction of the bishop of Breslau. Ten years later, the largely formal suffragan status of the Diocese of Breslau to the Polish primate at Gnesen (Gniezno) was abolished and the diocese became directly subject to the Holy See. (Köhler 1997; Wiskemann 1956: 23)

\section{From Talking to Language}

Following the changes in Silesia's political, administrative, and ecclesiastical boundaries summarized above, the boundaries remained mostly unchanged in the $19^{\text {th }}$ century, and indeed until after World War I. Thus, they constituted the framework within which the processes of modernization, urbanization, and industrialization were played out. Part and parcel of this vast social, economic, and political reordering was the unmitigated drive to replace Central Europe's anational political order of multiethnic empires with ethnolinguistically defined nation-states. The main step to this end was the abolition of the estate-versus-serfs cleavage, so that the entirety of a population perceived to speak a single language was to become a nation, in spite of any social or economic divisions within it. Serfdom was liquidated in the Habsburgs lands and Prussia at the turn of the $19^{\text {th }}$ century (its last remnants disappeared in the middle of that century), and at the same time free popular elementary education was instituted in both polities. The second half of the $19^{\text {th }}$ century was marked by the gradual disappearance of illiteracy and by the democratization of political life. On Prussia's 1871 founding of the German Empire as Central Europe's first-ever nation-state, all adult males obtained the right to vote, and in 1907 the same provision was extended to their counterparts in the Austrian half of Austria-Hungary (which had been established in 1867 through the constitutional reform of the absolutist Austrian Empire). Neither language nor faith was to bar an adult man from suffrage. These unprecedented changes were facilitated, financed, and accelerated by rapid industrialization and urbanization.

Silesia, or rather Prussian Upper Silesia and East Austrian Silesia, became the focus of these processes of change in Prussia (Germany) and Austria-Hungary respectively, due to the exploitation 
of the resources of the extensive coalfield in the area (then also shared by the adjacent Russian Empire). The mining and metallurgical industrial basin which emerged in eastern Upper Silesia was the second largest in Germany and on the continent as a whole (after the Ruhr basin), while that which developed in East Austrian Silesia was the largest in Austria-Hungary, and the third largest in continental Europe. Across the state border to the east of both these areas, the Dombrova (Dąbrowski) industrial basin developed in the Russian Empire. Besides catering for Russia's western provinces, much of its workforce also commuted on a daily basis or migrated westward to the two other industrial basins in Upper Silesia and Austrian Silesia in search of better pay, and improved working and living conditions. (Hytrek 1996 [1879]: 41, 64; Plaček 1996a; Schoffer 1974)

The process of dramatic change also influenced how people perceived themselves as groups (or nations) and their relations with states. Arguably one of the most salient changes in this regard was the fact that people stopped talking just to communicate, but first had to speak something reified as 'a language.' The European (Western) concept of 'a language,' intimately intertwined with writing, schooling, and popular literacy served two basic needs. Firstly (and analogously to the acquisition of numeracy) it supplied the workforce with a generic skill that transcended typical dialectal and linguistic differentiation among people, thus allowing one worker to replace another to carry out the same standardized task in a factory. Secondly, due to the ideological steeping of Central European nationalisms in language, written languages became instruments of mass mobilization, nation-, and nation-state-building. (Billig 1995: 30, 36; Gellner 2006 [1983]: 26-27, 34, 136) Speaking lost its innocence and became an act of self-identification regulated by politics, schools, and dictionaries. Since then, through language one has needed to negotiate one's national identity with one's interlocutor before genuine communication can proceed. States in Central Europe enforced this nationalization and politicization of language by making it into the presumably 'objective' sign of one's nationality. One had to declare it in censuses, beginning in 1861 in Prussia, in 1880 in Austria-Hungary, and in 1897 in Russia. (Leuschner 2004)

Significantly, because one could belong only to a single nation in line with the normative practice of nationalism, in the censuses a person could not declare more than one language as his or her own. This, on the one hand, glided over the typical phenomenon of everyday traditional (or predominantly oral) multilingualism (or rather 
di- or polyglossia ${ }^{5}$ ) in Central Europe, (cf Liszka 1996) and on the other, gradually, enforced monolingualism. State-sponsored and controlled universities made languages into discrete entities (despite the spatially, or geographically, continuous nature of language); this corresponded to the parallel project of establishing separate, ethnolinguistically-defined nation-states. Implicitly, it meant that nations enclosed within the boundaries of their nation-states should not share languages with one another. To each nation, its own national language. The early modern compromise of cuius regio, eius religio ${ }^{6}$ that underpinned the political order in Central Europe after the Treaty of Westphalia (1648) had concluded the period of the religious wars between Catholics and Protestants, was replaced with the novel national principle of cuius regio, eius lingua. ${ }^{7}$ The state administration and popular elementary education enforced this linguistic-cum-political equation. This is the normative substance of ethnolinguistic nationalism, rarely articulated in any explicit manner, but acted upon by governments and populaces at large in Central Europe. The success of this policy was such that from a global perspective, the region of Europe is unique in being divided among nation-states that predominantly do not (or strongly aspire not to) share their officialcum-national languages with other polities, and do not (or strive not to) have more than one official-cum-national language. ${ }^{8}$

\section{Silesia and Its Languages}

Since the late Middle Ages Silesia was the meeting point between the Germanic and North Slavic dialect continua. ${ }^{9}$ The Oder was a rough

\footnotetext{
5 The terms 'bi-, or multilingualism' assume full competence in two or more languages. However, in reality, a bi- or multilingual person tends to use the different languages he or she knows in different spheres of their private and public life. Hence, one is fluent in these various languages differently, depending on the situation. This is the gist of what di- or polyglossia is.

${ }^{6}$ From Latin: 'The ruler dictates the religion of his realm.'

7 From Latin: 'The ruler [meaning nation or the national movement] dictates the language of his realm [meaning, nation-state].'

${ }^{8}$ I dub this phenomenon the normative isomorphism (or tight spatial and ideological overlapping) of language, nation and state. This is treated in detail in Kamusella (2006).

${ }^{9}$ A 'dialect continuum' is a geographically contiguous area within which language forms (usually construed as 'dialects') change gradually from village to village, from city to city, from region to region without the loss of mutual intelligibility. Of course, the degree of mutual intelligibility decreases with distance, but nevertheless it is retained within a given continuum.

I speak of the 'Germanic continuum,' though the tradition is to dub it 'West Germanic,' on two counts. First, the East Germanic continuum became extinct with
} 
(and never absolute) dividing line between these two continua. However, decisions of lay and ecclesiastical lords to grant land for the purpose of founding a village or town for Germanic-, or less often, Slavic-speaking settlers led to the constant crossing and re-crossing of this river by peasants and burghers speaking dialects drawn from these two continua. Thus, a lattice of Germanic-speaking localities could be found in the predominantly Slavophone areas and vice versa.

This language difference was not of much consequence until the $19^{\text {th }}$ century. Silesia was part of the Western Christian world, with its spiritual-cum-cultural center in Rome, the pope's seat. So even though Silesia successively changed hands between Bohemia, Poland, the Czech Crown, the Holy Roman Empire, Hungary, or the Habsburg lands, the official language of Latin did not change. It was the language of administration, learning, and liturgy. Latin-based Christianity, and various cultural practices based on it, created a sphere of commonality for the entire population of the Western Christian world.

A rift in this commonality (though not an unbridgeable chasm, as some would like to see it) was introduced by the Hussite Wars in the first half of the $15^{\text {th }}$ century, followed by the Reformation, the CounterReformation, and the religious wars from the $16^{\text {th }}$ to the early $18^{\text {th }}$ century. Initially, the split between Catholics and Protestants did not mean a rapid change in official language use. However, the insistence of the Protestants on making the Bible available in vernaculars (or 'speech of common people') provided for the rise of literacies in languages other than Latin.

In the case of Central Europe, the basis for the rise of these vernacular literacies was the growing use of the chancery German(ic) language(s) (referred to as Theodisk, Teutsch, Tütsch, Düdesch, Deitsch, Duits, Dütsch, or Deutsch, thus, essentially by the same name, despite often significant differences existing between these

the disappearance of Crimean Gothic in the $16^{\text {th }}-18^{\text {th }}$ centuries. Secondly, the West Germanic and North Germanic (Scandinavian) continua have never been geographically separate, as proved time and again by intensive warfare, commerce and migrations in the basins of the Baltic and the North Sea.

Similarly, I use the term 'North Slavic continuum,' which clashes with the conventional classificatory division of the Slavic languages into the Eastern, Southern and Western branches. There has never been a geographical or social division between East and West Slavic-speakers, while the geographical division between them and South Slavic-speakers has been in place for a millennium, in the form of the swath of land populated by Finno-Ugric-speakers (Hungarians) and East Romance-speakers (Romanians and Moldovans) from today's Austria to the Black Sea. 
language ${ }^{10}$ ) since the $12^{\text {th }}$ century for administrative and literary pursuits, and of the Slavic vernacular of Bohemia (referred to as 'Slavic' or 'Bohemian'), since the $14^{\text {th }}$ century, used for the same purposes, and also for liturgical purposes. (The disagreement about the latter use was the spark that triggered the Hussite Wars.) In the $16^{\text {th }}$ century, Polish joined the club, when it became the sociolect of the nobility of Poland-Lithuania then at the apex of its power. (Eggers 1970; Kamusella 2009a; Tornow 2009: 95, 101, 129-136, 140-145)

The vicissitudes of the three-centuries-long religious strife left the western third of Prussian Silesia (Liegnitz Regency) overwhelmingly Protestant, its mid-section (Breslau Regency) of mixed Catholic-Protestant character, and its eastern one-third (Upper Silesia) overwhelmingly Catholic. To a degree this situation was reflected in Austrian Silesia, with its western section almost homogenously Catholic, while East (Austrian) Silesia was of mixed, CatholicProtestant, character. In all these cases the vast majority of the Protestants professed Lutheranism. (Bahlcke 1996: 94, 103)

When it comes to language, in the $13^{\text {th }}$ and $14^{\text {th }}$ centuries one of the chancery German(ic) languages made an appearance in Lower Silesia, where more Germanic-speakers lived than their Slavophone counterparts. However, by the $15^{\text {th }}$ and $16^{\text {th }}$ centuries it had become the language of all the Silesian princely courts. (Bindewald et al 19351936) Due to the strongly Slavic character of Upper Silesia, beginning in the $16^{\text {th }}$ century, chancery Bohemian began to replace chancery German(ic) there. Polish also made an entrance in Upper Silesia when the Duchy of Oppeln was briefly pawned to the Polish-Lithuanian king in the mid- $17^{\text {th }}$ century. In addition, until 1811 , the region's easternmost sliver constituted part of the Diocese of Cracow, which led to some use of Polish in ecclesiastical administration. Furthermore, frontiers were quite porous until the turn of the $19^{\text {th }}$ century, so in the border areas, cultural practices, including language use, penetrated from Poland-Lithuania to Silesia and vice versa. (Knop 1967: 6, 24; Köhler 1997: 2)

A change in this relaxed approach to language use came after Prussia's seizure of most of Silesia in 1740-42. In this absolutist polity, would-be standard German (or the language of Luther's translation of the Bible, based on the Germanic dialect of Meissen, geographically and dialectally very close to Silesia's Germanic dialects) was the official language. In the late $18^{\text {th }}$ century, the Habsburgs followed this policy in their hereditary lands, excluding Hungary (where Latin

\footnotetext{
${ }^{10}$ The similarity in the names survives in the case of the self-linguonyms Deutsch for German and Duits for Dutch, despite the fact that they evolved into two separate languages.
} 
remained official until 1846), but including Austrian Silesia. Instead of siding with 'Common German' of the imperial court in Vienna, they also chose Luther's German, which paved the way for the uncontested rise of pan-confessional standard German, as we know it today. Apart from Latin, which remained the language of Catholic liturgy worldwide until the late 1960s, German was the sole official language of Prussian and Austrian Silesia until the mid- $19^{\text {th }}$ century.

The partitions of Poland-Lithuania at the close of the $18^{\text {th }}$ century, in which Prussia, Russia, and the Habsburgs participated, added a new variable to this situation. First, having doubled its territory at the expense of Poland-Lithuania, between 1793 and 1807, Prussia became a bilingual, German-Polish state. However, this was a short-lived episode, as the Napoleonic onslaught reduced Prussia's intake of Polish-speaking lands, and after 1815 many of these territories were transferred to Russia. In contrast, a more durable Polish-language influence developed close by, north-east of Austria's East Silesia, where between 1815 and 1846 the Free City of Cracow existed with Polish as its official language, and a Polish-medium university where sons of the Polish-Lithuanian nobility were allowed to pursue their tertiary education. This influence was due to Vienna's de facto control of the free city and apparently did not extend to Prussia's Upper Silesia, though the Oppeln Regency bordered directly on this free city. Following the Polish-Lithuanian nobility's failed attempt at an uprising against the partitioning powers in 1846, the Austrian Empire annexed the Free City of Cracow, as the polity was the center of the attempted rebellion. As a result, the state border between this former Polish-Lithuanian capital and East Silesia disappeared.

The Year of Revolution, 1848, brought changes to Prussian Upper Silesia. Having recognized the need to enforce the provision of free popular elementary education in order to produce a literate workforce for the modernizing state of Prussia and its growing Upper Silesian industrial basin, the Catholic Church introduced Polish and Morawec (Moravian) ${ }^{11}$ as the media of education for Slavophone Catholics in Upper Silesia. ${ }^{12}$ Polish was introduced in the Diocese of Breslau and Morawec in Upper Silesia's southern sliver, which was part

\footnotetext{
${ }^{11}$ I use the term 'Morawec' for this language, though it basically means 'Moravian,' because the population concerned in southern Upper Silesia was referred to as Morawzen in German, Moravce in Czech, and Morawce in their own Morawec language. The standard ethnonym 'Moravians,' that is Mährer in German or Moravané in Czech was reserved for the inhabitants of Moravia, irrespective of their language, or to the crownland's Slavic-speakers. Unlike Morawecs, Slavophone Moravians used Antiqua for writing and printing their language. (Pallas 1970: 36-38) 12 Until the period between the two World Wars, the educational system in Prussia was run by the Catholic and Protestant Churches.
} 
of the Archdiocese of Olmütz. The choice of Polish did not mean that the Breslau ecclesiastical authorities perceived their Slavic-speaking faithful as Poles; basically, the language was close enough to the local Slavic dialect. This still a-national approach to language is more clearly visible in the decision of the Archdiocese of Olmütz to use the local dialect of southern Upper Silesia for the same purpose. It was a time of trying out different solutions in the drive to ensure effective education as the basis for mastering German (then the language of administration, business, and learning in Central Europe) in the later years of elementary school. The fact that Breslau settled for Polish written and printed in Antiqua, while Olmütz (Olomouc) used Morawec in the Gothic (Fraktur) type, was either a reflection of the lack of coordination in these efforts or of competition between the diocese and the archdiocese. (Plaček 1996b; Świerc 1990)

At the same time, the Protestant ecclesiastical authorities followed the example for Upper Silesia and north-eastern Lower Silesia, where their Slavic-speaking faithful were concentrated. They settled for Polish in elementary schools but written and printed in the Gothic type, which at that time was customarily employed for producing German-language books for their co-religionists. (Cf Fiedler 1987) In Austrian Silesia, the short-lived use of local Slavic dialects (termed 'Czech' and 'Polish,' the former in eastern West Silesia, and the latter in East Silesia) for educational purposes, as introduced in 1848 , terminated with the re-imposition of absolutism in 1851. (Gawrecka 1993: 68; Grobelný 1992: 60) In the 1860s, some Czechand Polish-language periodicals and organizations appeared, and following the 1867 liberalizing transformation of the Austrian Empire into Austria-Hungary, elementary and secondary schools with both Slavic languages as the media of education were founded. As language became the instrument of gradually accepted and condoned political mobilization in the Dual Monarchy, Slavic-speakers from West Silesia began to side with the mainstream Czech ethnolinguistic national movement, while their counterparts in East Silesia sided with the Polish movement. Both movements contested the East Silesian industrial basin and the western swath of East Silesia, considering them, respectively, 'rightly' Czech or Polish. In view of the fact that these potential Czechs and Poles spoke identical dialects, religion was employed to differentiate between them. The former were homogenously Catholic, while the latter lived in confessionally mixed villages and towns, in the general ratio of one-third Protestants to twothirds Catholics. Furthermore, all of East Silesia was included in the Diocese of Breslau, whose boundaries for Polish nationalists marked the 'historical' border of Poland; this view clashed with the Czech 
opinion that a future Czech nation-state should be composed of Bohemia, Moravia, and Silesia, as its historical regions.

In 1871 the German Empire was founded as the kernel of a future 'true' ethnolinguistic German nation-state. In line with this aspiration, all languages (including Morawec and Polish), other than German, were phased out from any administrative use and education by the mid-1870s. (Plaček 1996b: 7) Books and periodicals (mostly of a religious character) continued to be published in Polish and Morawec, and both languages were still used orally in religious contexts. However, north-eastern Lower Silesia's Slavophone Protestants made the switch from Polish into German, and by the turn of the $20^{\text {th }}$ century, the latter also became the language of their everyday communication. The inconsistency of Berlin's ennationalizing ${ }^{13}$ policies was visible in labeling Upper Silesia's Slavic population in the Diocese of Breslau as 'Poles' and 'Polish-speaking,' although the German administration did not consider them to be members of the Polish nation. This confusion stemmed from the earlier a-national employment of Polish in elementary education. (Cf Triest 1984 [1864])

\section{The Nationalization of Silesia's Languages}

The principle of the normative legitimization of statehood and nationhood through language became an increasingly accepted new standard in Central Europe prior to the Great War. Census returns on the language question provided national movements with demographic statistics of their respective nations-in-making. For the authorities in the German Empire it presented a distinctive challenge on the road to an ethnolinguistically homogenous Germany, which it proposed to tackle through compulsory elementary education in the exclusive medium of German. Across the frontier, in the Austrian half of AustriaHungary, the policy was of co-opting national movements through gaining their support for obtaining constitutional order by providing them with various cultural and linguistic concessions. Thus, in 1869 Polish replaced German as the sole official language of the Crownland of Galicia, whereas in 1880 Czech (Bohemian) and Moravian (Slavic) ${ }^{14}$

\footnotetext{
${ }^{13}$ I use the neologism to denote the process of making population into part, or individuals into members, of a nation, usually through cultural and linguistic assimilation. I decided to coin this term as the more natural choice of 'to nationalize' already has a well-established very specific economic meaning, that is, to make enterprises and agriculture state-owned.

${ }^{14}$ Czech nationalists did not recognize the official distinction between Czech (Bohemian) and Moravian (Slavic), that is, most commonly Böhmisch and Mährisch in German, and termed both languages 'Czech.'
} 
were introduced as second official languages in Bohemia and Moravia, respectively. In the wake of the 1905 compromise (Ausgleich), German and Moravian (Slavic) became co-official languages in Moravia. German remained the sole official language of Austrian Silesia, but this did not prevent the development of elementary and secondary education in Czech and Polish, though in reality local Slavic dialects were employed in the initial years of elementary school, and schools themselves were monolingual, bilingual, or even trilingual in Czech, German, and Polish. In 1907 (when universal male suffrage was introduced in the Austrian half of the monarchy), the same liberal approach to language use was extended to the communes in Austrian Silesia. They were at liberty to select their language(s) of local administration, thanks to which some communes conducted their business in one language, some in two, and others even in three, the languages of choice being Czech, German, and Polish. (Kamusella 2007: 216-218)

This political fixation on language in Central Europe made the use of language in censuses, administration, education, press, and book production the main arena of struggle for 'souls' among national movements in the region. (Cf Zahra 2008) In this process they brushed away the niceties of polyglossia and pressed people to side with a single language. (Cf King 2002) This was of the utmost importance for these movements in the context of such traditionally multilingual borderlands as Upper and Austrian Silesia, if, in the future, clear-cut borders of would-be ethnolinguistic nation-states were to be drawn there. (Cf Judson 2006) Paradoxically, this ethnolinguistic-cumpolitical struggle in both regions led to the mutual canceling-out of the influences of the Czech, German, and Polish national movements there. In reaction, the ethnic groups of the Morawecs, the Szlonzoks in Upper Silesia, and the Slunzaks in East Austrian Silesia ${ }^{15}$ emerged, each connected to specific traditions of multilingual language uses and religious practices in Upper and Austrian Silesia. (Kamusella 1998a; Pallas 1970)

As the ethnolinguistic and national polarization was more pronounced and not actively suppressed in Austria-Hungary (unlike in the German Empire), in 1909 the Slunzaks founded an ethnic political party. It sided with Austrian Silesia's German parties and advocated a regional East Silesian identity (hoping thus to minimize the Czech influence in East Silesia), alongside the use of German and Polish (but

\footnotetext{
${ }^{15}$ The self-ethnonyms 'Szlonzok' and 'Slunzak' are dialectal varieties for 'Silesian' as noted in Polish spelling. I do not conflate them, because the overwhelmingly Catholic Slavophone Szlonzoks of Upper Silesia and the confessionally mixed, CatholicProtestant Slavophone Slunzaks of East Silesia perceived themselves as constituting two separate (ethnic) groups. (Pallas 1970: 44)
} 
not Czech). Yet an intensification of political action conducted in the name of ethnolinguistic nations came in the aftermath of World War I, following the breakup of Austria-Hungary and the near-collapse of the German Empire. The Slunzakian party hoped to prevent the splitting of their East Silesian homeland between Poland and Czechoslovakia by making it into an 'East Silesian industrial nation-state,' or through its incorporation as a whole into Czechoslovakia. The Szlonzoks were faced with a similar dilemma as there was a drive to divide Upper Silesia between Germany and Poland. In 1919 they too founded an ethnic party with the purpose of either securing an independent Upper Silesian Free (nation-)State with German and Polish as co-official languages, or at least obtaining the status of a politically autonomous region within the boundaries of the German state.

Although the Szlonzokian party was the largest political force in Upper Silesia at that time, its wishes were not heeded. (SchmidtRösler 1999) Berlin was incapable of intervening and the Western Allies dictated the terms of the postwar settlement. The same was true of the situation in Austrian Silesia as there was no external source of effective support for the local Germans and Slunzaks. Hence, in 1920 East Silesia was split between Czechoslovakia and Poland; and two years later Upper Silesia was partitioned between Poland and Germany. In 1920, Prague also received from Upper Silesia the southern half of Ratibor (Racibórz) county, mostly populated by Morawecs that became known as the Hultschiner Ländchen in German or the Hlučínsko in Czech. ${ }^{16}$ In the respective sections of both regions, Czechizing, Germanizing, and Polonizing policies were pursued in the interwar period in order to ennationalize the borderlands' a-national people (or those with a 'wrong' or 'illegitimate' national identity, whether as Morawecs, Slunzaks or Szlonzoks) into one of the three internationally recognized nations of either Czech(oslovak) $\mathrm{s}^{17}$, Germans or Poles. (Bjork 2008: 196-213; Kamusella 2007: 235-236, 257-270) ${ }^{18}$ Perhaps the most visible sign of these policies was the dramatic changes in the names of localities and streets, often executed overnight, following partitions. (Cf Bugge 2004)

\footnotetext{
${ }^{16}$ I use the name 'Germany' as shorthand for the post-1918 German Empire. The polity retained its official name until 1945, but after the abdication of Wilhelm II no later emperor ascended to the empty throne.

${ }^{17}$ I play with this ethnonym a bit, because Czechoslovakia was officially founded as a nation-state for the Czechoslovak nation, speaking its own Czechoslovak language. In reality, Czechs and Slovaks continued to exist as two different nations with their separate national languages. (Cf Maxwell 2009:142-162, 166-186.)

18 In the case of Germans in Czechoslovakia and Poland it meant one of the relatively unknown cases of ethnic cleansing, see Blanke (1993).
} 
Before 1918, the Catholic Church strove to moderate ethnolinguistically based national polarization, drawing on the resources of the faith's universalism. As late as the interwar period, this was visible in the local clergy's equivocation in matters national as proved by their studiously non-ideological approach to the question of language use in religious instruction and pastoral care. (Bjork 2008: 65-76) The success of ennationalizing policies in Poland's sections of Upper and East Silesia, organized as the Voivodeship of Silesia (województwo śląskie), and in Prague's Czech Silesia, was mixed. Although many Slunzaks quickly began to identify as Poles in the voivodeship, most Szlonzoks stuck to their ethnic identification and persisted in pro-German attitudes, as evidenced by their votes for German minority parties and their persistence in sending their children to German-language minority schools, despite the voivodeship authorities' steps to prevent them from doing so. Despite the fact that the democratic order ended in 1926 in Poland and in 1933 in Germany, until 1937, the League of Nations curbed the most radical assimilatory measures in Germany's and Poland's sections of Upper Silesia. Yet it was not enough in the eyes of the initially even pro-Polish Szlonzoks who felt betrayed by Poland. With their language derided as 'corrupt Polish,' desirable positions in the voivodeship's civil service and companies went to 'indubitable' Poles from outside Upper Silesia. In response, Szlonzokian activists organized the revealingly named Zwiazek Obrony Górnoślązaków (Association for the Defense of the Upper Silesians [or Szlonozks]) in 1925. (Gerlich 1994; Jerczyński 2006: 204-220, 223-227; Wanatowicz 1982) Similarly, Slunzakian identification survived in Czech Silesia, and because Germans formed a plurality in this administrative region, in 1928 it was dissolved and incorporated into Moravia. At the same time, Morawecs persisted in their bilingualism and continued sending their children to Germanmedium minority schools despite hurdles put in their path by the Czechoslovak administration. To Prague's horror, they declared themselves to be Germans. (Chocholatý 1991; Götze 1997)

Interestingly, the German authorities of the Province of Upper Silesia (into which Berlin's section of Upper Silesia was formed within the Land of Prussia in 1923), faced with the undeniable Slavophone character of many Upper Silesians, emphasized that these Slavicspeakers were not Poles, but Szlonzoks, construed as eigensprachiger Kulturdeutsche, or 'non-German-speaking Germans, (cf Blanke 2001) united with the German nation through shared German culture.' This Szlonzokian Adoptivstamm ('adopted tribe') of the German nation was encouraged to develop, cultivate, and declare its bilingualism, as summarized in the standard declaration of 'two mother tongues,' Szlonzokian (or Oberschlesisch in German) at home, and German in 
official contexts. (Eichenberger 1994: 36); Kneipp 1999: 137-138;

Pallas 1970: 30-31)

The relative success of this German approach to the question of how to include Szlonzoks in the German nation without alienating them through straightforward Germanization stemmed from the tacit recognition of the fact that non-linguistic elements of social reality may also determine both one's nationality and one's perception of one's vernacular. From this perspective, Szlonzokian could be credibly presented as a Kulturmundart ('cultural dialect') of the German language, despite its undeniably Slavic character, if the non-linguistic ethnographic continuum of German culture (or of Central European culture, posited as 'German') were considered of more significance than language itself. (Blachetta 1939: 9-11; Hannan 1996: 57; Nieborowski 1919: 145; Schmid-Rohr 1932: 177-178) This conviction that Szlonzokian is a dialect of the German language survives among some ethnic Poles listening to their Szlonzokian neighbors talk in Upper Silesia to this day. (Wyderka 1998)

\section{The Creole and Totalitarianisms}

This ambivalence as to whether to classify Szlonzokian as a Slavic or Germanic dialect also stemmed from the development of the little researched phenomenon of the Upper Silesian Slavic-Germanic creole. ${ }^{19}$ In the last three decades of the $19^{\text {th }}$ century, Upper Silesia's industrial basin grew rapidly, attracting usually German-speaking managers and Slavic- and German/Germanic-speaking workers. They had to communicate unambiguously across the language divide in factories and collieries, or at home when they married across this linguistic cleavage. To this end they developed a specific SlavicGermanic pidgin, not unlike the Bantu-Germanic pidigin of Fanagalo, (Adendorff 2002) which emerged in the South African industrial basin

\footnotetext{
${ }^{19}$ When I applied the concepts of pidgin and creole to the analysis of Upper Silesia's linguistic reality for the first time in 1998 (cf Kamusella 1998b), the immediate reaction, which smacked of the times from before the fall of communism in 1989, was that the head of the institute in which I was then employed at the University of Opole, Poland, forbade me to use these terms in any Polish-language publications. He argued that these concepts could be applied, for instance, in an African context, but not in Poland, a 'civilized state.' Furthermore, the terms simply did not exist in the Polish language. Hence, should I really want to employ them, first I ought to obtain approval to do so from the prescriptivist quarterly Język Polski (The Polish Language, Cracow). With the privilege of hindsight, I believe that the person's reaction had something to do with the still cherished national belief, developed at the turn of the $20^{\text {th }}$ century, that Polish has been a unitary, homogenous language from time immemorial, and that all the Poles have always spoken it.
} 
of the Witwatersrand at the same time. Later, in contrast to the latter case, in Upper Silesia the sustained intensive interaction between Slavic- and German/Germanic-speakers spawned a generation for whom this pidgin was their first language, thus, a creole, disparagingly known as Wasserpolnisch (or 'watered-down, corrupted Polish') in German. A similar Slavo-Germanic pidgin/creole also developed in the Czech Silesian industrial basin of Ostrava-Karviná, but on a smaller scale due to the more homogenously Slavophone character of the former East Austrian Silesia (with the exception of the Germanophone 'island' of Bielsko and the adjacent Galician town of Biała).

Due to the strong link with the adjacent countryside of the Upper Silesian basin's workforce (commuting from villages to factories and mines, or tending, after hours, to small holdings on the outskirts of towns or in villages, which led to the rise of the memorable figure of the 'peasant-worker' [or chłoporobotnik in Polish]), the creole spread to rural areas, too. In 1938, German was imposed as the sole medium of education in Germany's Province of Upper Silesia, while Polish was similarly imposed in the voivodeship. During World War II, all of Upper Silesia, together with the adjacent counties of the voivodeships of Cracow and Kielce, were incorporated into Germany. The use of Polish was banned and replaced with German. After 1945, the interwar voivodeship was returned to Poland and the interwar Province of Upper Silesia was incorporated into this country, together with most of the German territories east of the Oder-Neisse line (or deutsche Ostgebiete, less the northern half of East Prussia which was incorporated into the Soviet Union), which became known in Polish as the 'Recovered Territories' (Ziemie Odzyskane). (Linek 2000) Not surprisingly, the officially termed 'transfer' (or rather ethnic cleansing) of the population considered to be German was followed by a ban on the use of German in public or private. German-language books and inscriptions were destroyed. (Kamusella 1998c; Kamusella 2009b; Linek 2010; Wurbs 1982)

Most of Upper Silesia's population was retained as 'autochthons,' or 'ethnic Poles not (fully) aware of their Polishness.' The pragmatic reason behind this decision was as follows: the output of the industrial basin was indispensable for the reconstruction of Poland, and there was no pool of 'indubitably Polish' workers with the required qualifications who could replace the Upper Silesian workforce. As a result, autochthons were retained as second-class citizens, but in everyday social practice were mistrusted as 'crypto-Germans,' for whom elementary and vocational education had to suffice. Such frequent and dramatic changes in language policies imposed from above after 1938 led to the spread of the use of the creole, which depending on the situation was becoming either more German/ic or 
more Slavic/Polish. The endogamic isolation of Upper Silesia's autochthons and their constant outflow to West Germany from 1950 to 1993 deepened this tendency until the 1980s, when the persistent economic crisis in communist Poland made autochthons into soughtafter spouses; by marrying them, people could leave for the West. (Kamusella 1999; Linek 2001)

This phenomenon of continuous emigration to West Germany kept replenishing the creole (or, in other cases, Slavic dialect[s]) with Germanisms. The emigrants had an increasingly antiquated knowledge of German if born prior to the mid-1930s, or almost no knowledge of this language when born shortly before or after 1945 . Thus, they rarely mastered German, and their language remained infused with Slavic/Polish linguistic loans. On the contrary, their children brought up or already born in West Germany speak and write almost exclusively in German and know only a handful of creole expressions. However, beginning in the 1970s, these emigrants were allowed to visit their families in Poland which led to the boosting of the Germanic dimension of the creole (dialects) in Upper Silesia.

The re-Germanization of the creole (dialects) intensified after the fall of communism when the teaching of German was permitted in Upper Silesia and the German minority was recognized in Poland. At the time of writing, about 250,000 autochthons living in Upper Silesia have received German citizenship and passports. (Kamusella 2003: 712) This has allowed them to undertake legal seasonal or permanent work in Germany since the early 1990s, thus, reinvigorating the knowledge of the creole (or, though to a lesser extent, of dialects) among the Upper Silesian emigrants in Germany and de-Polonizing this creole (and sometimes, dialects) in Upper Silesia itself. ${ }^{20}$

\section{After 1989: Language and Perception, and Politics}

There is no linguistic definition of 'a language.' What a language is is decided by politics, that is, actual language use in conjunction with relevant legislation on such use. The stronger the politicization of

\footnotetext{
20 These processes had their parallels, but on a smaller scale, in Czech Silesia. (I refrain from describing them in detail due to the article's brevity.) Following the expulsion of Germans from Czechoslovakia, the Slavophone character of Czech Silesia was reinforced. Processes similar to Slavo-Germanic creolization in Upper Silesia unfolded in the Ostrava-Karviná basin, and in the Hlučínsko (before 1920, part of Upper Silesia). However, the influx of Indic-speaking Roma from Slovakia to the aforementioned basin during the communist period had no parallel in Poland's Upper Silesia. The same was true of the preservation of Polish-medium minority schools and official bilingualism in Czech Silesia's communes with a Polish minority. (Cf Plaček 2000)
} 
language use (as in Central and Eastern Europe), the more decisions on what a language is are detached from the actual linguistic reality. These aim to transform the description of the linguistic reality and then the reality itself in line with the current (usually national) ideological ideas and needs. For instance, Moldovan continues to be a separate language only due to political contingency, though it is practically identical to Romanian. Likewise, Low German is considered a dialect of German, though it is mutually comprehensible with Dutch, unlike with standard German.

At present, in Upper Silesia both standard Polish and the creole/dialect(s) are used in parallel on an everyday basis and are transmitted within families. Some autochthons (especially in the territory of the interwar Province of Upper Silesia, to a degree overlapping with today's Voivodeship of Opole) acquire German at school and during seasonal or permanent work in Germany. German is of much less interest to ethnic Poles (who mostly arrived there after $1945)^{21}$ and autochthons in eastern Upper Silesia (or today's Voivodeship of Silesia). Today, both Upper Silesia's ethnic Poles and autochthons strive to master English, but only in its function as the global lingua franca, which (at least as of now) has no visible bearing on their identity.

Interestingly, but not atypically, autochthons speaking the creole/dialect(s) sometimes interpret what it is quite differently, though predictably in line with, their identificational choices. Hence, those who consider themselves to be Germans use the creole/dialect(s) as a sign of their non-Polishness because in most cases they have no or scant knowledge of German. Some even see it still as a dialect of the German language. Not surprisingly, the creole/dialect(s) appears to be a dialect of Polish in the eyes of those autochthons who define themselves as Poles. In the two most recent Polish censuses over 170,000 autochthons declared themselves to belong to the Silesian nation in 2002, and 0.85 million in 2011. According to them the creole/dialect(s) is nothing else but their national language of 'Silesian' (corresponding to Szlonzokian, of which

\footnotetext{
${ }^{21}$ The apparently unambiguous category of 'ethnic Poles' is quite deceptive in the case of Upper Silesia. Some stem from the interwar group of ethnic Poles who had come to the region after 1922, and had been expelled after 1939. However, most arrived after World War II, either as settlers from central Poland or expellees from the Polish eastern territories incorporated into the Soviet Union. The latter continued to arrive in Poland (and Upper Silesia) until 1958. Last but not least, a considerable group of Szlonzoks (autochthons) also consider themselves to be ethnic Poles. Differences in language and customs between these groups of ethnic Poles used to be quite pronounced in the past. The mass media and compulsory popular education have leveled them out.
} 
I wrote above). (Polish Census of 2002 2009; Przynależność narodowo-etniczna ludności 2013: 3) ${ }^{22}$

Nowadays, in Poland, from the ethnolinguistic vantage, Upper Silesia (split between the voivodeships of Opole and Silesia ${ }^{23}$ ) is the country's most multiethnic and multilingual region. A single village or town there may be inhabited by Germans, Poles, and Silesians, who speak German/Silesian, Polish, and Silesian. ${ }^{24}$ However, in many cases these three languages may happen to be the same creole/dialect(s), and the actual experience of multilingualism may be limited to codeswitching between it and standard Polish. (Cf Kamusella 2004; Kamusella 2005-2006; Tambor 2006; Wanatowicz 2004)

\section{References}

Adendorff, Rajend. 2002. Fanakalo: A Pidgin in South Africa (ch 9). In: Rajend Mesthrie, ed. Language in South Africa. Cambridge: Cambridge University Press. Bahlcke, Joachim et al. 1996. Schlesien und die Schlesier. Munich: Langen Müller.

Billig, Michael. 1995. Banal Nationalism. London: Sage. Bindewald, Helene; Burdach, Konrad and Piurs, Paul. 1935-1936. Deutsche Texte aus schlesischen Kanzeleien des 14. und 15. Jahrhunderts (Ser: Vom Mittelalter zur Reformation: Forschungen zur Geschichte der deutschen Bildung, vol 9). Berlin: Weidmann.

\footnotetext{
22 In Czech Silesia, 44,000 people declared themselves to be of Silesian (or Slunzakian) nationality in the 1991 census, but the number of these declarations dropped to 25 per cent, to 11,000 in the 2001 census. (Slezská národnost ve sčítání lidu 2001 2007) Unlike in Poland's Upper Silesia, in Czech Silesia there have been no concentrated attempts to declare or codify the local dialects (creole) as a Silesian language, though Óndra Łysohorsky did actually create such a language in his poetry written from the 1930s to the 1980s. However, he called his language 'Lachian,' not Silesian. (Hannan 1996: 112, 152) Furthermore, in the Hlučínsko, the indigenous population prefers to dub the local dialect (creole?) as the Prussian language (prajzská mluva in Czech). (Melecká 2008)

${ }^{23}$ Today's curiously named Voivodeship of Silesia was known as the Voivodeship of Katowice before 1999. Its territory contains only one third of what were the historically Upper Silesian lands.

${ }^{24}$ At present, users of the Silesian language strive for its official recognition in Poland. To this end, they secured the ISO 639-3 szl code for it in 2007, launched the Ślünsko Wikipedyjo (Silesian Wikipedia) a year later, and held two codification conferences in Katowice in 2008 and 2009. They also published several dictionaries of codifying aspirations, the most ambitious being: Wielki słownik śląsko-niemieckoangielski (Czajkowski et al 2006) and Słownik polsko-śląski / Zbornik polsko-ślůnski (Roczniok 2007-).
} 
Bjork, James E. 2008. Neither German nor Pole: Catholicism and National Indifference in a Central European Borderland. Ann Arbor: University of Michigan Press.

Blachetta, Walther. 1939. Das wahre Gesicht Polens. Berlin: Verlag "Die Wehrmacht".

Blanke, Richard. 1993. Orphans of Versailles: the Germans in Western Poland, 1918-1939. Lexington: University of Kentucky Press.

Blanke, Richard. 2001. Polish-speaking Germans? Language and National Identity among the Masurians since 1871. Cologne: Böhlau.

Bugge, Peter. 2004. The Making of a Slovak City: The Czechoslovak Renaming of Pressburg/Pozsony/Prešporok, 1918-19 (pp 205227). Austrian History Yearbook. Vol 35.

Celati, Gianni. 1989. My Uncle Discovers the Existence of Foreign Languages (pp 111-112). In: Gianni Celati. Voices from the Plains (translated by Robert Lumley). London: Serpent's Tail. Chocholatý, František. 1991. Slezsko [Silesia \{in Czech\}] (Part 4) (pp 76-97). Střední Evropa. No 20.

Czajkowski, Andrzej; Schröder, Lidia and Schröder, Sandra. 2006. Wielki słownik śląsko-niemiecko-angielski [Geat SilesianGerman-English Dictionary \{in Polish\}]. Katowice: KaGaDruk.

Eggers, Hans, ed. 1970. Der Volksname Deutsch (Ser: Wege der Forschung, vol 156). Darmstadt: Wissenschaftliche Buchgesellschaft.

Eichenberger, Carsten. 1994. Die Deutschen in Polen. Von der verleugneten Minderheit zur anerkannten Volksgruppe. Augsburg: Bukowina-Institut.

Fiedler, Robert. 1987. Tam jeszcze kęs polactwa. Wybór pism pastora $z$ Międzyborza [Some Polishness Still Remained There: A Selection of the Writings by a Pastor from Międzybórz \{ in Polish\}]. In: Gajda, Stanisław, ed. . Opole: Instytut Śląski.

Gawrecka, Maria. 1993. Problematyka narodowościowa Śląska austriackiego w latach 1742-1914 [The Ethnolinguistic Make-Up of Austrian Silesia in 1742-1914 \{in Polish\}] (pp 61-74). Studia Śląskie. Vol 52.

Gellner, Ernest. 2006 [1983] Nations and Nationalism. Oxford: Blackwell.

Gerlich, Marian Grzegorz. 1994. „Śląska krzywda” - przejaw zbiorowego poczucia poniżenia wśród górnośląskiej ludności rodzimej (okres międzywojnia) [The Silesian Tragedy: Collective Humiliation Experienced by Upper Silesia's Indigenous Population (During the Interwar Period) \{in Polish\}] (pp 5-23). Etnografia Polska. No 1-2.

Götze, Andreas. 1997. Private Communication. Opole. 
Grobelný, Andělin. 1992. Śląsk Cieszyński od Wiosny Ludów do samodzielnych państw (1848-1918) [Cieszyn Silesia from the Spring of Nations to the Independent States (1848-1918) \{ in Polish\}]. In: Zarys dziejów Śląska Cieszyńskiego. Ostrava and Prague: Komitet Czeskiej Administracji Terenowej.

Hannan, Kevin. 1996. Borders of Language and Identity in Teschen Silesia (Ser: Berkeley Insights in Linguistics and Semiotics, vol 28). New York: Peter Lang.

Hytrek, Adolf. 1996 [1879]. Górny Szlązk pod względem obyczajów, języka i usposobienia ludności [Upper Silesia: The Indigenous Population's Customs and Languages \{in Polish\}]. Opole: Związek Górnoślązaków and Solpress.

Jerczyński, Dariusz. 2006. Historia Narodu Śląskiego. (Prawdziwe dzieje ziem śląskich od średniowiecza do progu trzeciego tysiaclecia) [The History of the Silesian Nation: The True History of the Silesian Lands from the Middle Ages to the Turn of the Third Millennium \{in Polish\}]. Zabrze: Narodowa Oficyna Śląska. Judson, Pieter M. 2006. Guardians of the Nation: Activists on the Language Frontiers of Imperial Austria. Cambridge MA: Harvard University Press.

Kamusella, Tomasz. 1998a. Wyłanianie się grup narodowych i etnicznych na Śląsku w okresie 1848-1918 [The Emergence of the National and Ethnic Groups in Silesia from 1848-1918 \{in Polish\}] (pp 35-72). Sprawy Narodowościowe. No 12-13.

Kamusella, Tomasz. 1998b. Kreol górnoślaski [The Upper Silesian Creole \{in Polish\}] (pp 73-84). Kultura i Społeczeństwo. No 1. Kamusella, Tomasz. 1998c. Das oberschlesische Kreol: Sprache und Nationalismus in Oberschlesien im 19. und 20. Jahrhundert (pp. 142-161). In: Markus Krzoska and Peter Tokarski, eds. Die Geschichte Polens und Deutschlands im 19. und 20. Jahrhundert. Ausgewäh/te Beiträge (Ser: Veröfentlichungen der DeutschPolnischen Historischen Gesellschaft, Vol 1). Osnabrück: Fibre.

Kamusella, Tomasz. 1999. Ethnic Cleansing in Silesia 1950-89 and the Ennationalizing Policies of Poland and Germany (pp 51-74). Patterns of Prejudice. No 2.

Kamusella, Tomasz. 2003. Dual Citizenship in Opole Silesia in the Context of European Integration. Facta Universitatis. (Niš, Serbia).

Kamusella, Tomasz. 2004. Standaryzacja języka górnośląskiego i możliwe konsekwencje społeczne i polityczne (ze szczególnym uwzględnieniem Śląska Opolskiego) [The Standardization of the Upper Silesian Language and the Potential Social and Political Ramifications (with a Special Attention Devoted to Opole Silesia) \{in Polish\}] (pp 113-132) Sprawy Narodowościowe. No 23-24. 
Kamusella, Tomasz. 2005-2006. Schlonzska mowa. Język, Górny Śląsk i nacjonalizmy [The Silesian Language: Language, Upper Silesia and Nationalisms \{in Polish\}] (2 vols). Zabrze: Narodowa Oficyna Śląska.

Kamusella, Tomasz. 2006. The Isomorphism of Language, Nation, and State: The Case of Central Europe (pp 57-92). In: W Burszta, T Kamusella and S Wojciechowski, eds. Nationalisms Across the Globe: An Overview of Nationalisms of State-Endowed and Stateless Nations (Vol 2: The World). Poznań, Poland: Wyższa Szkoła Nauk Humanistycznych i Dziennikarstwa.

Kamusella, Tomasz. 2007. Silesia and Central European Nationalisms: The Emergence of National and Ethnic Groups in Prussian Silesia and Austrian Silesia. West Lafayette IN: Purdue University Press. Kamusella, Tomasz. 2009a. Language in Central Europe's History and Politics (pp 7-25). Sprawy Narodowościowe. No 34.

Kamusella, Tomasz. 2009b. Echanges de paroles ou de coups en Haute-Silésie: la langue comme "lieu" de contacts et de luttes interculturels ( $\mathrm{pp}$ 133-152). Cultures d'Europe centrale. No 8: Lieux communs de la multiculturalité urbaine en Europe centrale, ed by Delphine Bechtel and Xavier Galmiche. Paris: CIRCE.

King, Jeremy. 2002. Budweisers into Czechs and Germans: A Local History of Bohemian Politics 1848-1948. Princeton NJ: Princeton University Press.

Kneipp, Matthias. 1999. Die deutsche Sprache in Oberschlesien. Untersuchungen zur politischen Rolle der deutschen Sprache als Minderheiten Sprache in den Jahren 1921-1998 (Ser: Veröffentlichungen der Forschungstelle Ostmitteleuropa and der Universität Dortmund, vol B 62). Dortmund: Forschungstelle Ostmitteleuropa.

Knop, Alois. 1967. Dějiny českého jazyka ve Slezsku a na Ostravsku [The History of the Czech Language in Ostrava Region \{in Czech\}]. Ostrava: Socialistická akademie.

Köhler, Joachim. 1997. Bistum Breslau (Vol 3: Neuzeit, 1740-1945). Güterbahnhof: Echo-Buchverlags and Münster: Apostolicher Visitator der Priester und Gläubigen aus dem Erzbistum Breslau.

Komarek, Ernst. 1998. Industralisierung Oberschlesiens. Zur Entwicklung der Montaninindustrie im überregionalen Vergleich. Bonn: Kulturstiftung der deutschen Vertriebenen.

Krallert, Wilfried; Kuhn, Walter and Schwarz, Ernst. 1958. Atlas zur Geschichte der deutschen Ostsiedlung. Bilefeld: Velhagen \& Klasing.

Kries, Karl Gustav. 1842. Historische Entwicklung der Steuerverfassung in Schlesien. Breslau: Georg Phlilipp Aderholz. 
Leuschner, Torsten. 2004. Richard Böckh (1824-1907): Language Statistics Between National Principle and National State (pp 389421). Historiographia Linguistica. No 2-3.

Linek, Bernard. 2000. Mit Ziem Odzyskanych w powojennej Polsce na przykładzie Górnego Śląska (wybrane aspekty) [The Myth of the Recovered Territories in Postwar Poland, as Exemplified by Upper Silesia: Selected Aspects \{in Polish\}] (pp. 229-257). In: Bernard Linek and Kai Struve, eds. Nacjonalizm a tożsamość $w$ Europie Środkowo-Wschodniej w XIX i XX w./Nationalismus und nationale Identität in Ostmitteleuropa im 19. und 20.

Jahrhundert. Opole: Instytut Śląski and Marburg: HerderInstitut.

Linek, Bernard. 2001. Próba eliminacji języka niemieckiego na Górnym Śląsku w latach 1945-1950 [The Attempt at Liquidating the German Language in Upper Silesia in 1945-1990 \{in Polish\}] (pp. 81-102). Przegląd Zachodni. No 1.

Linek, Bernard. 2016 [Forthcoming]. Robotnicy Borsigwerku. Procesy akulturacji/asymilacji wśród robotników górnośląskich (od drugiej połowy XIX wieku do pierwszej polowy XX wieku) [The Borsigwerk Workers: The Processes of Acculturation / Assimilation Among Upper Silesia's Workers from the Second Half of the 19th Century to the First Half of the 20th Century \{in Polish\}]. In: Robert Traba, ed. Akulturacja/asymilacja na pograniczach kulturowych Europy Środkowo-Wschodniej w XIX $i$ $X X$ wieku (vol 2). Warsaw: Instytut Studiów Politycznych PAN and Niemiecki Instytut Historyczny.

Liszka, Józef. 1996. Das Tauschkind-System im slowakischen Teil der Kleinen Tiefbene (pp 58-72). Zeitschrift für Balkanologie. No 32.

Lubos, Arno. 1995. Geschichte der Literatur Schlesiens (Vol I.1: Von den Anfängen bis zu ca. 1800). Würzburg: Bergstadtverlag.

Maxwell, Alexander. 2009. Choosing Slovakia: Slavic Hungary, the Czechoslovak Language and Accidental Nationalism (Ser: International Library of Political Studies, vol 37). London: Tauris Academic Studies, an imprint of I B Tauris.

Melecká, Liana. 2008. Prajzská mluvčí: Valaši mají krále, my Moniku Žídkovou [Sopeaking in the Prussian language: Valachians Have Their King, and We Have our Monika Žídkova \{in Czech\}]. Dnes (Insert: Ona), Feb 8. http://ona.idnes.cz/prajzska-mluvci-valasimaji-krale-my-moniku-zidkovou-p0wLona ony.asp?c=A080206 105014 ona ony jup, Nov 24, 2009. Nieborowski, Paul. 1919. Oberschlesien, Polen und der Katholizismus. Berlin: Engelmann. 
Orzechowski, Kazimierz. 1971. Terytorialne podziały na Śląsku [Territorial Divisions in Silesia \{in Polish\}] (pp 53-69). Kwartalnik Opolski. No 2.

Pallas, Ladislav. 1970. Jazyková otázka a podmínky vytvaření národního vědomí ve Slezsku [The Language Question and the Emergence of National Consciousness in Silesia \{in Czech\}]. Ostrava, Czechoslovakia: Profil.

Plaček, Vilém. 1996a. Hans Kudlich osvoboditel rakouských poddanch [Hans Kudlich: The Liberator of Austrian Serfs \{in Czech\}] (pp. 18-20). Vlastivědne listy. No. 1.

Plaček, Vilém. 1996b. Hlučínští Moravci v Pruskm Slezsku a jeich spajatost s Katolickou Církví do sjednocení Německa roku 1871 [The Hlučín Morawecs and Their Attachment to the Catholic Church Until the Unification of Germany in 1871 \{in Czech\}] (pp. 5-8). Vlastivědne listy. No. 2.

Plaček, Vilém. 2000. Prajzáci aneb k osudům Hlučínska, 1742-1960 [Prussians or the Fate of Hlučín Region, 1742-1960 \{in Czech\}]. Hlučín: Kulturné a vzdělávaci společnost' Hlučínsko i Kravaře and Zámecké museum.

Polish Census of 2002. 2009. http://en.wikipedia.org/wiki/Polish census of 2002, Apr 8.

Przynależność narodowo-etniczna ludności - wyniki spisu ludności i mieszkań 2013 [The Ethno-National Identity of the Population: The Results of the 2011 Census of Population and Accommodation \{in Polish\}]. 2013. http://www.stat.gov.pl/cps/rde/xbcr/gus/LUD_raport_z_wynikow _NSP2011.pdf, May 25, 2014.

Roczniok, Andrzej. 2007-. Słownik polsko-śląski / Zbornik polskoślünski [The Polish-Silesian Dictionary \{in Polish and Silesian\}] (vols 1 and 2). Zabrze: Narodowa Oficyna Śląska.

Schmidt-Rohr, Georg. 1932. Die Sprache als Bildner in der Völker: eine Wesens- und Lebenskunde der Volkstümer. Jena: Diederichs.

Schmidt-Rösler, Andrea. 1999. Autonomie- und Separatismusbesterbungen in Oberschlesien 1918-1922 (pp 149). Zeitschrift für Ostmitteleuropa-Forschung. No 1.

Schoffer, Lawrence. 1974. The Formation of a Modern Labor Force: Upper Silesia 1865-1914. Berkeley CA: University of California Press.

Slezská národnost ve sčítání lidu 2001 [The Silesian Nationality in the Czech Census of 2001 in Czech\}]. 2007. http://dalsimoravak.bloguje.cz/585759-slezska-narodnost-vescitani-lidu-2001.php, Nov 23, 2009. 
Stüttgen, Peter; Neubach, Helmut and Hubatsch, Walther. 1976. Grundri zur deutschen Verwaltungsgeschichte,1815-1945 (Ser A: Preußen, vol 4: Schlesien). Marburg: Herder-Institut. Świerc, Piotr. 1990. Ks. Bernard Bogedain (1810-1860) [Ft Bernard Bogedein (1810-1860) \{in Polish\}] (Ser: Wszechnica Muzeum Śląskiego). Katowice: Muzeum Śląskie.

Tambor, Jolanta. 2006. Mowa Górnoślązaków oraz ich świadomość językowa i etniczna [The Language of the Upper Silesians and Their Linguistic and Ethnic Identity \{in Polish\}] (Ser: Prace Naukowe Uniwersytetu Śląskiego, Vol 2401). Katowice: Wydawnictwo Uniwersytetu Śląskiego.

Tornow, Siegfried. 2009. Abendland und Morgenland im Spiegel ihrer Sprachen. Ein kulturhistorischer Vergleich. Wiesbaden: Harrassowitz.

Triest, Felix. 1984 [1864]. Topographisches Handbuch von Oberschlesien (2 vols) (Ser: Beiträge zur Geschichte und Landeskunde Oberschlesiens, vol 1). Sigmaringen: Jan Thorbecke.

Wanatowicz, Maria Wanda. 1982. Ludność napływowa na Górnym Śląsku w latach 1922-1939 [Polish Migrants in Upper Silesia, 1922-1939 \{in Polish\}]. Katowice: Uniwersytet Sląski.

Wanatowicz, Maria Wanda. 2004. Od indyferentnej ludności do śląskiej narodowości? Postawy narodowe ludności autochtonicznej Górnego Śląska w latach 1945-2003 w świadomości społecznej [From the Nationally Indifferent Population to a Silesian Nationality? The National Attitudes of the Autochthonous Population of Upper Silesia between 1945 and 2003, as Reflected in Social Consciousness \{in Polish\}] (Ser: Prace Naukowe Uniwersytetu Śląskiego w Katowicach, Vol 2224). Katowice: Wydawnictwo Uniwersytetu Śląskiego.

Wiskemann, Elizabeth. 1956. Germany's Eastern Neighbours: Problems Relating to the Oder-Neisse Line and the Czech Frontier. London: Oxford University Press and Royal Institute of International Affairs.

Wurbs, Gerhard. 1982. Die deutsche Sprachinsel Bielitz-Biala (Ser: Eckartschriften, Vol 79). Vienna: Österr. Landsamannschaft.

Wyderka, Bogusław. 1998. O konieczności nowych badań gwar ślaskich [On the Necessity of Renewed Reserach on the Silesian Dialects \{in Polish\}] (pp. 1-4). Śląsk Opolski. No. 3.

Zahra, Tara. 2008. National Indifference and the Battle for Children in the Bohemian Lands 1900-1948. Ithaca: Cornell University Press. 